MA'ALIM: Jurnal Pendidikan Islam

Volume 1, Nomor 1, Juli 2020

\title{
PENGARUH MENGIKUTI UNIT BISNIS TERHADAP PENINGKATAN KETERAMPILAN DAN MOTIVASI BERWIRAUSAHA PADA SANTRI
}

\author{
Deni Anggrayani \\ Universitas Darussalam Gontor \\ denitea690gens@gmail.com
}

\author{
Ari Susanto \\ Universitas Darussalam Gontor \\ denitea690gens@gmail.com
}

\author{
Safiruddin Al Baqi \\ IAIN Ponorogo \\ albaqi@iainponorogo.ac.id
}

\begin{abstract}
As education systems, Islamic boarding school has several advantages such as teaching religious knowledge, science and various extracurricular activities. Modern Islamic Boarding School of Darussalam Gontor Inodonesia is a boarding school that has a holistic education system, which is not only educate the academic skill but also educate students in developing entrepreneurship skills. This study aims to determine the effect of joining the business unit to the motivation and ability of entrepreneurship among students. This research used ethnography method with interviews and observations in business units in Darussalam Gontor. The results of this study indicate that Darussalam Gontor is a boarding school which implements 24-hour education system with various activities, such as praying togather, muajjah, learning in class, sports, mahkamatul lughoh and others. Differences of Darussalam Gontor with other boarding school is because Darussalam Gontor requires senior student to be responsible for business unit, such as Darussalam Press, Wisma Darussalam, La Tansa bookstore and other units. Result of this study shows that after joining the business unit, students become more motivated to develop their own business. Students also get enough knowledge to start a business or become an entrepreneur. The data showed that many alumni who have success become entrepreneurs. The entrepreneur character is heavily influenced by the role of alumni as a student of Darussalam Gontor. The alumni's businesses include production of songkok, ice cream, bookstore, travel agent, garment businessman and others.
\end{abstract}

Keywords: business unit, education system, entrepreneurship, Islamic boarding school, Islamic education

\begin{abstract}
Abstrak
Sebagai sistem pendidikan, pesantren memiliki beberapa keunggulan seperti mengajarkan ilmu agama, sains dan berbagai kegiatan ekstrakurikuler. Pondok Modern Darussalam Gontor Inodonesia adalah pesantren yang memiliki sistem pendidikan holistik, yang tidak hanya mendidik keterampilan akademis namun juga mendidik siswa dalam mengembangkan keterampilan kewirausahaan. Penelitian ini bertujuan untuk mengetahui pengaruh bergabungnya unit bisnis terhadap motivasi dan kemampuan berwirausaha antar siswa. Penelitian ini menggunakan metode etnografi dengan wawancara dan observasi pada unit
\end{abstract}


MA'ALIM: Jurnal Pendidikan Islam

Volume 1, Nomor 1, Juli 2020

bisnis di Darussalam Gontor. Hasil penelitian ini menunjukkan bahwa Darussalam Gontor adalah pesantren yang menerapkan sistem pendidikan 24 jam dengan berbagai kegiatan, seperti sholat, muajjah, belajar di kelas, olahraga, mahkamatul lughoh dan lain-lain. Perbedaan Darussalam Gontor dengan pesantren lainnya adalah karena Darussalam Gontor mewajibkan siswa senior untuk bertanggung jawab atas unit bisnis, seperti Darussalam Press, Wisma Darussalam, toko buku La Tansa dan unit lainnya. Hasil penelitian ini menunjukkan bahwa setelah bergabung dengan unit bisnis, siswa menjadi lebih termotivasi untuk mengembangkan bisnis mereka sendiri. Siswa juga mendapatkan cukup pengetahuan untuk memulai bisnis atau menjadi entrepreneur. Data tersebut menunjukkan bahwa banyak alumni yang telah sukses menjadi wirausahawan. Karakter pengusaha sangat dipengaruhi oleh peran alumni sebagai mahasiswa Darussalam Gontor. Bisnis alumni meliputi produksi songkok, es krim, toko buku, agen perjalanan, pengusaha garmen dan lain-lain.

Kata kunci: kewirausahaan, pendidikan Islam, pesantren, sistem pendidikan, unit usaha,.

\section{PENDAHULUAN}

Terdapat berbagai system pendidikan yang diterapkan di sekolah sekolah saat ini di seluruh dunia. Dari berbagai system pendidikan yang ada beberapa diantaranya mempu bertahan dan mampu menjawab tantangan global, namun ada pula yang tidak mampu berkembang. Salah satu system pendidikan yang mampu berkembang dan mampu mebjadi solusi bagi kebutuhan masyarakat, khususnya di Indonesia saat ini adalah system pendidikan pesantren. Pondok pesantren merupakan lembaga pendidikan islam tradisional yang aktivitasnya adalah mempelajari, memahami, mendalami, menghayati, dam mengamalkan ajaran islam dengan menekankan pada pentingnya moral keagamaan sebagai pedoman perilaku sehari-hari ${ }^{1}$.

Nurcholish Madjid menegaskan bahwa pondok pesantren adalah artefak peradaban Indonesia yang dibangun sebagai institusi pendidikan keagamaan bercorak tradisional, unik, dan indigenous ${ }^{2}$. Pondok pesantren memilki dua fungsi utama, yaitu fungsi kegiatan tafaqqahu fi al-din (pengajaran, pemahaman, dan pendalaman ajaran agama islam), serta fungsi indzhar (menyampaikan dan mendakwahkan ajaran kepada masyarakat) ${ }^{3}$.

Seiring perkembangan zaman, pondok pesantren semakin kuat memberikan pengaruh bagi masyarakat seperti dalam bidang politik dan ekonomi. Pengaruh aspek politik tampak dari banyaknya partai di Indonesia yang berbasis agama sedangkan dari aspek ekonomi tampak dari munculnya system perbankan syariah yang semakin diminati. Salah satu pondok pesantren yang memiliki pengaruh besar di Indonesia adalah Pondok Modern Darusslam Gontor (PMDG).

\footnotetext{
${ }^{1}$ Mastuhu, Dinamika Sistem Pendidikan Pesantren (Jakarta: INIS XX, 1994).

${ }^{2}$ Nurcholish Madjid, Bilik-Bilik Pesantren, (Jakarta: Dian Rakyat, 1997)

${ }^{3}$ Didin Hafidhuddin, Dakwah Aktual (Jakarta: Gema Insani, 1998).
} 
MA'ALIM: Jurnal Pendidikan Islam

Volume 1, Nomor 1, Juli 2020

Darussalam Gontor adalah sebuah institusi pendidikan yang didirikan berdasarkan ajaran Islam dengan menjadikan kyai sebagai sentral figure dan masjid sebagai titik yang menjiwainya.. Pesantren ini didirikan pada tanggal 20 September 1926 oleh tiga bersaudara, KH. Ahmad Sahal, KH. Zainuddin Fannani, dan KH. Imam Zarkasyi (Staff Sekretariat PMDG). Pondok Modern Darussalam Gontor Indonesia adalah pesantren yang memiliki sistem pendidikan holistik, yang tidak hanya mendidik keterampilan akademis namun juga mendidik siswa dalam mengembangkan keterampilan kewirausahaan.

PMDG memberikan fasilitas kepada siswanya untuk belajar soft skill diluar kelas melalui berbagai kegiatan seperti organisasi pelajar, pramuka, seni bela diri marching band dan bayak kegiatan yang lain. disamping itu, siswa kelas akhir juga dibekali dengan keterampilan berwirausaha dengan memberikan mereka tanggung jawab untuk menjalankan unit business yang dimiliki PMDG. Unit business tersebut meliputi koperasi pelajar, pabrik dan toko roti, toko buku, dan lain lain. Disana mereka ditempatkan diberbagai posisi, seperti berperan sebagai staff hingga supervisor di unitunit tersebut. Melalui kurikulum ini, siswa diharapkan memiliki bekal dan latihan yang cukup untuk menumbuhkan kemampuan dan motivasi dalam entrepreneurship.

Teori nurture mengatakan bahwa keterampilan kewirausahaan dipengaruhi oleh lingkungan seperti keluarga. Namun nature juga berperan, seperti faktor biologis dan keadaan hormonal. Penelitian terkini memberikan bukti baru bahwa kedua aspek tersebut sama-sama memiliki peran penting terhadap keterampilan kewirausahaan, yakni latar belakang keluarga bisnis yang memberikan proses pembelajaran dari kecil dan level hormone testosterone yang tinggi yang berpengaruh terhadap kondisi fisik dan psikologis seseorang ${ }^{4}$. Dengan demikian, kemampuan entrepreneurship memerlukan latihan intensif dan hal ini dapat dicapai dengan lebih mudah jika entrepreneurship dimasukkan dalam kurikulum sekolah.

Meskipun kurikulum kewirausahaan umumnya diterapkan di vocational school atau sekolah kejuruan, tapi saat ini banyak diantara Pondok Pesantren yang menerapkannya. Kurikulim entrepreneurship di pondok pesantren bisa menjadi wadah berlatih yang strategis sehingga mencapai hasil yang maksimal. Salah satunya karena mereka hidup bersama dan berlatih bersama teman sejawat mereka selama 24 jam. Penelitian Falck, Heblich dan Luedemann menemukan bahwa memiliki kelompok sejawat kewirausahaan memiliki efek positif pada niat kewiraswastaan individu. Ditemukan pula bahwa kekuatan efek peer ini dipengaruhi oleh nilai-nilai yang berlaku

${ }^{4}$ White, Thornill, Hompson, A biosocial model of entrepreneurship: combined effects of nurture and nature, (Journal of Organizational Behavior, 28(4), 1997) hal. 451-466. 
MA'ALIM: Jurnal Pendidikan Islam

Volume 1, Nomor 1, Juli 2020

dalam kelompoknya sehingga menular ke yang lain ${ }^{5}$. Leibenstein mengungkapkan bahwa latihan merupakan hal yang sangat penting untuk meningkatkan keterampilan kewirausahaan, meskipun tidak semua karakteristik kewirausahaan dapat dilatih ${ }^{6}$. Selain PMDG, contoh yang lain adalah Pondok Pesantren Roudhotul Khuffadz Indonesia. Santri dibekali keterampilan bertani yang bertujuan untuk menggali potensi dan menyiapkan diri santri agar siap di masyarakat ${ }^{7}$.

Manfaat dari adanya pembelajaran kewirausahaan bagi peserta didik adalah mampu menciptakan kompetensi entrepreneurship seperti mengetahui bagaimana cara memasarkan produk, melatih siswa memiliki jiwa mandiri, ulet dan bertanggung jawab, menjadikan siswa sebagai manusia yang mau maju, mandiri dan berkembang, sebagai sarana menciptakan unit usaha di sekolah dalam rangka menuju kemandirian sekolah, sebagai bekal bagi siswa untuk menciptakan lapangan kerja sendiri serta dapat mencetak seorang wirausaha yang mandiri dan professional ${ }^{8}$. Lebih lanjut, Tyson, Petrin dan Rogers mengungkapkan bahwa pengembangan kewirausahaan sangat penting dilakukan dalam sebuah Negara untuk meningkatkan perekonomian mereka. Sehingga pemerintah memiliki peran sentral guna memberikan kebijakan-kebijakan, seperti dalam kurikulum pendidikan entrepreneurship hingga kebijakan ekonomi praktis ${ }^{9}$.

Dari penjelasan diatas, dapat disimpulkan bahwa Pondok Pesantren memiliki beberapa keunggulan seperti mengajarkan ilmu agama, sains dan berbagai kegiatan ekstrakurikuler. PMDG adalah pesantren yang memiliki sistem pendidikan holistik, yang tidak hanya mendidik keterampilan akademis namun juga mendidik siswa dalam mengembangkan keterampilan kewirausahaan. Penelitian ini bertujuan untuk mengetahui pengaruh bergabungnya unit bisnis terhadap motivasi dan kemampuan berwirausaha antar siswa.

\section{METODE}

Penelitian ini menggunakan metode kualitatif dengan pendekatan etnografi, yaitu deskripsi dan interpretasi dari budaya atau kelompok atau sistem sosial ${ }^{10}$. Dengan

${ }^{5}$ Falck, Heblich, \& Luedemann, Identity and entrepreneurship: do school peers shape entrepreneurial intentions, (Small Business Economics, 39(1), 2012) hal. 39-59.

${ }^{6}$ Leibenstein, Entrepreneurship and Development. (The American Economic Review, 58(2), 1968), hal. 72-83.

${ }^{7}$ Wekke, Pesantren dan pengembangan kurikulum kewirausahaan: kajian Pesantren Roudahtul Khuffadz Sorong Papua Barat. (Inferensi, 6(2), 2012), hal. 205-226.

8 Abdul Hakim, Model Pengembangan Kewirausahaan Sekolah Menengah Kejuruan (SMK) dalam Menciptakan Kemandirian Sekolah. (Riptek, 4(1), 2010), hal. 1 - 14

${ }^{9}$ Tyson, Petrin, \& Rogers, Promoting Entrepreneurship in Eastern Europe. (Small Business Economics, 6(3), 1994), hal. 165-184.

${ }^{10}$ Creswell, Qualitative inquiry and research design : Choosing among five tradition. (London: SAGE Publication Inc., 1998) 
MA'ALIM: Jurnal Pendidikan Islam

Volume 1, Nomor 1, Juli 2020

tujuan untuk memperoleh gambaran mendalam mengenai pengaruh system pendidikan di PMDG khususnya unit usaha terhadap keterampilan kewirausahaan siswa. Pengumpulan data dilakukan melalui wawancara dan observasi. Observasi dilakukan dengan cara mengikuti kehidupan partisipan di lingkungan asli mereka yaitu PMDG. Sedangkan wawancara dilakukan pula terhadap alumni PMDG.

Participant penelitian ini adalah 7 orang siswa dan alumni PMDG (6 laki-laki and 1 perempuan). Berikut uraian dan pelak-sanaan pada setiap tahap etnografis; (1) tahap penjajakan atau orientasi lapangan (grand tour), (2) tahap perumusan temuan awal dan penentuan strategi penelitian, (3) tahap ana-lisis data lanjutan, (4) tahap pemeriksaan ke-absahan data, (5) tahap analisis data akhir dan perumusan hasil penelitian, (6) tahap pem-buatan laporan, (7) tahap pasca-laporan.

\section{HASIL DAN PEMBAHASAN}

Dari penelitian ini didapatkan beberapa temuan penting terkait pengaruh bergabung dengan unit usaha tethadap diri santri PMDG. Secara umum pengaruh ini dapat dikategorikan pada dua aspek, yaitu aspek psikologis dan aspek keterampilan atau hard skill. Ditemukan pula bahwa ada faktor-faktor lain yang mendukung karir entrepreneurship siswa setelah menjadi alumni dan memiliki bisnis. Pembahasan ini akan dijabarkan sebagai berikut:

\section{Pengaruh terhadap aspek psikologis}

Aspek psikologis yang pertama adalah Motivasi. Pada beberapa kasus, motivasi untuk memiliki usaha atau menjadi entrepreneur telah dimiliki siswa sebelum bergabung dengan unit usaha PMDG. Namun demikian, bergabung denga unit usaha membuat santri lebih termotivasi untuk memiliki usaha sendiri setelah mereka lulus dari PMDG. Motivasi ini diperoleh dari rekan satu unit dan senior mereka yang selalu mendampingi. Tidak hanya mampu memotivasi diri sendiri namun mereka juga mampu memotivasi rekan santri yang lain ketika menghadapi masalah. Hal ini muncul karena kedekatan yang terjadi selama mereka bergabung dalam satu unit dan menghadapi berbagai masalah yang ada bersama-sama.

Pengaruh kelompok sejawat terhadap motivasi berwira usaha juga ditemukan di penelitian lain, yaitu penelitian yang dilakukan di sekolah oleh Falck, Heblich dan Luedemann ${ }^{11}$. Penelitian ini menemukan bahwa memiliki kelompok sejawat kewirausahaan memiliki efek positif pada niat kewiraswastaan individu. Ditemukan pula bahwa kekuatan efek peer ini dipengaruhi oleh nilai-nilai yang berlaku dalam

\footnotetext{
${ }^{11}$ Falck, Heblich, \& Luedemann, Identity and entrepreneurship: do school peers shape entrepreneurial intentions, (Small Business Economics, 39(1), 2012) hal. 39-59.
} 
MA’ALIM: Jurnal Pendidikan Islam

Volume 1, Nomor 1, Juli 2020

kelompoknya sehingga menular ke yang lain. selain itu, Pendidikan berbasis kewirausahaan dan bisnis management memberikan dampak yang signifikan terhadap motivasi siswanya dalam membangun usaha sendiri ${ }^{12}$.

Aspek psikologi yang kedua adalah disiplin, utamanya disiplin waktu. Selain belajar sebagai siswa, siswa yang bergabung dengan unit usaha harus mengerjakan tugas unit usalah yang cukup menyita waktu mereka. Hal ini membuat mereka harus mampu mengatur waktu dengan baik karena mereka terkadang harus bekerja lebih dari jam kerja. Seperti bagian koperasi yang hampir setiap hari harus menyiapkan dan memerhatikan susunan produk yang tersedia dan berdisiplin dalam menjalankan jam buka dan jam tutup pada koperasi. Pola hidup disiplin akan mampu melatih profesionalisme individu, dan hal ini sangat dibutuhkan bagi seorang entrepreneurship. Penelitian Farhadudin terkait profesionalisme guru PMDG menjelaskan bahwa terdapat beberapa aspek yang mempengaruhi profesionalisme guru PMDG yaitu adanya dogma-dogma yang ditanamkan meliputi (1) hidupilah pondok dan jangan menggantungkan kehidupan kepada pondok (2) pondok adalah tempat ibadah dan thalabul'ilmi (3) pondok berdiri di atas dan untuk semua golongan ${ }^{13}$.

Aspek psikologi yang selanjutnya adalah Keikhlasan, kejujuran dan tanggung jawab. Ketiga karakteristik ini saling berhubungan seiring pengalaman yang siswa dapatkan selama bergabung dengan unit usaha. Dengan memahami tujuan dari koprasi pelajar, yaitu usaha yang memiliki prinsip tidak mengambil untung sebanyak banyaknya tetapi lebih belajar keikhlasan dan bagaimana memajukan unit usaha tersebut. Dengan prinsip how to give not how to take. terlebih lagi ketika melihat banyak uang yang dihasilkan perharinya, melatih rasa agar tidak rasa ingin mencurinya karena itu bukan uang kami tapi uang umat. Dengan demikian rasa tanggung jawab dan kejujuran juga terlatih.

Leibenstein menyatakan bahwa pelatihan bisa meningkatkan kemampuan kewirausahaan. Jelas, tidak semua karakteristik pengusaha bisa dilatih. Bagi sebagian besar siswa, belajar di dunia kerja tampaknya menjadi pengalaman penting ${ }^{14}$. Sementara Valo menjelaskan praktikum tersebut nampaknya berperan penting dalam proses pembelajaran menuju profesionalisme. Ini memberi mereka gagasan yang bermanfaat, memberi mereka kesempatan untuk refleksi diri dan penilaian diri, memperkuat rasa percaya diri mereka, berfungsi sebagai tinjauan terhadap studi sebelumnya, mendorong mereka untuk melanjutkan studi akademis, menawarkan

${ }^{12}$ Vinten \& Alcock, Entrepreneuring in education, (The International Journal of Educational Management, 18(3), 2004), hal. 188-195.

${ }^{13}$ Farhadudin, Manajemen peningkatan profesionalisme Ustadz di Pondok Modern Darussalam Gontor Ponorogo Jawa Timur. (Tesis UIN Sunan Kalijaga Yogyakarta, 2015)

${ }^{14}$ Leibenstein, Entrepreneurship and Development. (The American Economic Review, 58(2), 1968), hal. $72-83$. 
MA’ALIM: Jurnal Pendidikan Islam

Volume 1, Nomor 1, Juli 2020

kesempatan untuk memeriksa persyaratan sosial dan profesional. di tempat kerja, dan membantu mereka dalam perencanaan karir mereka ${ }^{15}$.

Abubakar mengusulkan sebuah kurikulum sekolah yang is sebut dengan Pesantren Kejuruan ${ }^{16}$. Usaha mewujudkan Pesantren Kejuruan ini sesuai dengan semangat Islam yang sangat menjunjung tinggi nilai-nilai sosial. Seorang muslim tidak hanya menjadi orang yang saleh individu, tetapi juga saleh secara sosial. Alumni Pesantren Kejuruan diharapkan dapat mengaplikasikan ilmunya, mampu bersaing di dunia kerja serta dapat mengabdikan diri dalam masyarakat. Dan hal ini sebenarnya sudah diterapkan di PMDG yakni dengan melibatkan siswa dalam unit bisnis PMDG.

\section{Pengaruh terhadap keterampilan entrepreneurship}

Keterampilan entrepreneurship yang pertama adalah Melatih kemampuan praktis. Kemampuan ini meliputi kemampuan menghitung dengan cepat, menyusun laporan dengan rapi dan kemampuan praktis lain seperti desain kaos. Kebanyakan siswa yang bergabung dengan unit usaha tertentu maka ia akan memiliki keinginan untuk memiliki usaha yang serupa. Seperti siswa yang bergabung dengan unit foto kopi, ia ingin memiliki bisnis di bidang foto kopi dan percetakan. Hal ini dikarenakan ia telah memiliki bekal kemampuan dan keterampilan dasar yang cukup untuk memulai usaha yang serupa. Hal ini senada dengan temuan Wekke di Pesantren Roudahtul Khuffadz Sorong Papua Barat, ia menemukan bahwa Santri dibekali keterampilan bertani yang bertujuan untuk menggali potensi dan menyiapkan diri santri agar siap di masyarakat ${ }^{17}$.

Aspek yang kedua adalah Kemampuan mengelola usaha. Selain kemampuan atau keterampilan praktis, siswa juga terlatih dalam mengelola sebuah organisasi atau bisnis. Kemampuan ini berkembang seiring dengan pengalaman siswa menjadi anggota ataupun manager dari sebuah unit usaha. Mereka belajar bagaimana menjadi anggota yang baik dan juga bagaimana ketika ia harus memimpin dengan pengalaman ataupun pengamatan yang mereka lakukan. Sehingga mereka memiliki prinsip "siap dipimpin dan siap memimpin".

Aspek selanjutnya adalah Memahami pasar (konsumen dan distributor). Dengan interaksi intensif yang mereka lakukan dengan santri sebagai konsumen serta dpihak lain seperti distributor, mereka mampu memahami perbedaan sifat dan latar blakang para konsumen dan distributor. Hal ini tentu mengasah soft skill mereka

\footnotetext{
15 Valo, Experiencing Work as a Communications Professional: Students' Reflections on Their OffCampus Work Practice, (Higher Education. 39(2), 2000), hal. 151-179.

${ }^{16}$ Abubakar, Pesantren kejuruan: Suatu alternatif pengembangan lembaga pendidikan Islam. Published on Proceeding of Annual International Conference of Islamic Studies (AICIS) 12th in Surabaya, 2012.

${ }^{17}$ Wekke, Pesantren dan pengembangan kurikulum kewirausahaan: kajian Pesantren Roudahtul Khuffadz Sorong Papua Barat. (Inferensi, 6(2), 2012), hal. 205-226.
} 
MA’ALIM: Jurnal Pendidikan Islam

Volume 1, Nomor 1, Juli 2020

sebagai seorang wirausahawan. Dan Aspek yang terakhir adalah Keuletan (rasa pantang menyerah). Dengan kesibukan sebagai pelajar dan siswa yang bergabung dengan unit usaha, mereka terlatih untuk bekerja keras , berfikir kritis , dan terus aktif dan terus berinovasi dalam memajukan suatu bidang yang sedang di jalani .

Peran pembimbing sangat diperlukan dalam menumbuhkan motivasi siswa dalam berwira usaha. Peran pembimbing diantaranya memberi tahu semua tentang bagian tersebut, entah dari segi kekurangan maupun segi kelebihan yang di miliki oleh bagian tersebut, serta mengarahkan tugas, kewajiban maupun hal hal yang di larang dalam bagian tersebut. Mengontrol dan mengevaluasi program kerja yang telah di sepakati pada meeting sebelumnya. Serta sebagai tempat konsultasi tentang beberapa inovasi yang ingin dilakukan pada program kerja atau ivent tertentu. Dalam hal ini pembimbing memiliki peran yang sngat penting dalam memberikan pengalaman kewirausahaan. Hal yang sama dikemukakan oleh McLarty yang menyatakan bahwa pengalaman berlatih wirausaha sangat penting untuk membangun motivasi dan keterampiran wirausaha ${ }^{18}$.

Dari penjelassan diatas dapat disimpulkan bahwa keika siswa bergabung dengan bisnis unit di PMDG, maka mereka memiliki berbagai pengalaman yang mampu membuat mereka merasa siap menjadi wirausaha. Penelitian yang dilakukan oleh McLarty di Inggris menunjukkan bahwa mayoritas lulusan universitas belum memiliki kesiapan untuk menjadi wirausahawan. hal ini karena mereka belum memiliki bekal yang cukup untuk menjadi eorang entrepreneur, karena untuk menjadi seorang entrepreneur yang menguasai bidang bisnis dan financial diperlukan latihan. Sedangkan universitas kurang memperhatikan masalah tersebut ${ }^{19}$.

\section{Faktor lain yang mempengaruhi entrepreneurship}

Hasil wawancara yang dilakukan dengan alumni PMDG menemukan bahwa terdapat faktor-faktor pendukung selain pengaruh joining the business unit in PMDG. Faktor tersebut meliputi peran keluarga dan motivasi internal untuk menjadi pengusaha.

Faktor pendukung yang pertama adalah Latar belakang keluarga. Beberapa partisipan mengungkapkan bahwa mereka memiliki latar belakang keluarga yang emiliki bisnis tertentu. Hal ini berpengaruh terhadap pola piker siswa yang mengikuti pola pikir orang tua, serta keterampilan-keterammpilan tertentu yang bisa diajarkan orang tua terhadap anaknya. Meski demikian, ada juga alumni yang sebenarnya tidak memiliki usaha keluarga namun mampu mengembangkan bisnis sendiri. McLarty juga menemukan bahwa ada dukungan keluarga yang signifikan, yang terbukti membantu

\footnotetext{
${ }^{18}$ McLarty, Entrepreneurship among graduates: towards a measured response. (Journal of Management Development, 24(3), 2005), hal. 223-238.

19 Ibid.
} 
MA'ALIM: Jurnal Pendidikan Islam

Volume 1, Nomor 1, Juli 2020

mendorong peluncuran bisnis, walaupun hanya sedikit bukti yang ditemukan mengenai investasi keuangan keluarga ${ }^{20}$. Koranti menemukan bahwa Lingkungan keluarga merupakan variabel yang memiliki pengaruh yang lebih kuat dibanding lingkungan sekitar terhadap minat berwirausaha ${ }^{21}$

Faktor yang kedua adalah motivasi yang kuat untuk menjadi pengusaha. Motivasi internal untuk menjadi pengusaha (sebelum dengan bergabung dengan unit usaha) dan dikombinasi dengan latihan setelah bergabung dengan unit usaha memberikan dampak begitu kuat terhadap siswa untuk mendirikan perusahaan sendiri.

Koranti dalam penelitiannya menemukan bahwa motivasi berwirausaha mempengaruhi sikap berwirausaha. Motivasi berwirausaha bisa tercapai dengan baik bila orang tersebut mempunyai kompetensi yang baik. Jika motivasi kewirausahaan rendah, maka daya saing juga akan rendah pula. Penelitian juga menemukan adanya pengaruh signifikan dari faktor internal (kepribadian dan motivasi) terhadap minat berwirausaha. Motivasi merupakan variabel yang memiliki pengaruh yang lebih kuat disbanding kepribadian terhadap minat berwirausaha ${ }^{22}$

\section{KESIMPULAN}

Hasil penelitian ini menunjukkan bahwa PMDG adalah pesantren yang menerapkan sistem pendidikan 24 jam dengan berbagai kegiatan, seperti sholat, muajjah, belajar di kelas, olahraga, mahkamatul lughoh dan lain-lain. Perbedaan Darussalam Gontor dengan pesantren lainnya adalah karena Darussalam Gontor mewajibkan siswa senior untuk bertanggung jawab atas unit bisnis, seperti Darussalam Press, Wisma Darussalam, toko buku La Tansa dan unit lainnya. Secara umum, pengaruh ini dapat dikategorikan menjadi dua aspek, yaitu aspek psikologis dan keterampilan keras atau aspek keterampilan kewirausahaan. Juga ditemukan bahwa ada faktor lain yang menunjang karir kewirausahaan mahasiswa setelah menjadi alumni dan memiliki usaha. Siswa menjadi lebih termotivasi untuk mengembangkan bisnis mereka sendiri. Siswa juga mendapatkan cukup pengetahuan untuk memulai bisnis atau menjadi entrepreneur. Data tersebut menunjukkan bahwa banyak alumni yang telah sukses menjadi wirausahawan. Karakter pengusaha sangat dipengaruhi oleh peran alumni sebagai mahasiswa Darussalam Gontor. Bisnis alumni meliputi produksi songkok, es krim, toko buku, agen perjalanan, pengusaha garmen dan lain-lain.

Dari hasil penelitian ini, penulis menyarankan kepada masyarakat untuk memilih program pendidikan yang memiliki unsure yang lengkap, yaitu pendidikan

\footnotetext{
20 Ibid.

${ }^{21}$ Koranti, Analisis pengaruh faktor eksternal dan internal terhadap minat berwirausaha. Published on Proceeding PESAT (Psikologi, Ekonomi, Sastra, Arsitektur \& Teknik Sipil) in Bandung, 2013. 22 Ibid.
} 
MA’ALIM: Jurnal Pendidikan Islam

Volume 1, Nomor 1, Juli 2020

agama serta pendidikan entrepreneurship guna membekali pemuda untuk menghadapi globalisasi. Sedangkan kepada Pengelola institusi pendidikan, penulis menyarankan agar menerapkan pendidikan agama, sains dan kewirusahaan. Pendidikan agama bertujuan untuk membentuk siswa berakhlaq karimah, pendidikan formal untuk mencapai kemampuan akademik siswa serta pendidikan kewirausahaan untuk membarikan soft skill yang dibutuhkan siswa saat mereka lulus.

\section{DAFTAR PUSTAKA}

Abubakar, M. (2012). Pesantren kejuruan: Suatu alternatif pengembangan lembaga pendidikan Islam. Published on Proceeding of Annual International Conference of Islamic Studies (AICIS) $12^{\text {th }}$ in Surabaya, 2012.

Creswell, J. W. (1998). Qualitative inquiry and research design : Choosing among five tradition. London: SAGE Publication Inc.

Falck, O., Heblich, S. \& Luedemann, E. (2012). Identity and entrepreneurship: do school peers shape entrepreneurial intentions. Small Business Economics, 39(1), 39-59.

Farhadudin, M. (2015). Manajemen peningkatan profesionalisme Ustadz di Pondok Modern Darussalam Gontor Ponorogo Jawa Timur. Tesis UIN Sunan Kalijaga Yogyakarta.

Hafidhuddin, Didin. (1998). Dakwah Aktual. Jakarta: Gema Insani.

Hakim, Abdul. (2010). Model Pengembangan Kewirausahaan Sekolah Menengah Kejuruan (SMK) dalam Menciptakan Kemandirian Sekolah. Riptek, 4(1), 1 - 14.

Koranti, K. (2013). Analisis pengaruh faktor eksternal dan internal terhadap minat berwirausaha. Published on Proceeding PESAT (Psikologi, Ekonomi, Sastra, Arsitektur \& Teknik Sipil) in Bandung, 2013.

Leibenstein, H. (1968). Entrepreneurship and Development. The American Economic Review, $58(2), 72-83$.

Mastuhu. 1994. Dinamika Sistem Pendidikan Pesantren. Jakarta: INIS XX

McLarty, R. (2005). Entrepreneurship among graduates: towards a measured response. Journal of Management Development, 24(3), 223-238.

Tyson, L., Petrin, T. \& Rogers, H. (1994). Promoting Entrepreneurship in Eastern Europe. Small Business Economics, 6(3), 165-184. 
MA’ALIM: Jurnal Pendidikan Islam

Volume 1, Nomor 1, Juli 2020

Valo, M. (2000). Experiencing Work as a Communications Professional: Students' Reflections on Their Off-Campus Work Practice. Higher Education. 39(2), 151-179.

Vinten, G. \& Alcock, S. (2004). Entrepreneuring in education. The International Journal of Educational Management, 18(3), 188-195.

Wekke, I. S. (2012). Pesantren dan pengembangan kurikulum kewirausahaan: kajian Pesantren Roudahtul Khuffadz Sorong Papua Barat. Inferensi, 6(2), 205-226.

White, W.E., Thornill, S. \& Hompson, E. (2007). A biosocial model of entrepreneurship: combined effects of nurture and nature. Journal of Organizational Behavior, 28(4), 451-466. 